\title{
TP53 NP_000537.3:p.R273H
}

National Cancer Institute

\section{Source}

National Cancer Institute. IP53 NP 000537.3:p.R273H. NCI Thesaurus. Code C146915.

A change in the amino acid residue at position 273 in the cellular tumor antigen p53

protein where arginine has been replaced by histidine. 